\title{
Estrogen effects on fetal and neonatal testicular development
}

\author{
Géraldine Delbès $^{1,2,3}$, Christine Levacher ${ }^{1,2,3}$ and René Habert ${ }^{1,2,3}$ \\ ${ }^{1}$ Univ Paris 7-Denis Diderot, Fontenay-aux-Roses, F-92265 France, ${ }^{2}$ CEA, DSV/DRR/SEGG/LDRG, Fontenay-aux- \\ Roses, F-92265 France and ${ }^{3}$ INSERM, U566, Unit of Gametogenesis and Genotoxicity, Fontenay-aux-Roses, \\ F-92265 France
}

Correspondence should be addressed to R Habert who is now at Unitè Gamètogenèse et Gènotoxicitè, Univ Paris 7, Denis Diderot, CEA, INSERM U566, CEA/DSV/DRR/SEGG/LDRG, Bat. 5A, RDC, Route du Panorama, 92265 Fontenay-aux-Roses, France; Email: rene.habert@cea.fr

\begin{abstract}
In recent years, evidences have accumulated that exposure to environmental components with estrogenic activity causes reproductive disorders in human populations. Studies conducted over the past $\mathbf{5 0}$ years have clearly shown a continual decline in semen quality accompanied by an increase in male reproductive disorders during this period in industrial countries. As healthy gametes are a prerequisite for healthy children, such disorders are a significant problem not only for the current society, but also for future generations. These male reproductive disorders have been attributed to xenobiotics, and particularly to xenoestrogens, which have steadily increased in diversity and concentration in the environment and food. Epidemiological, clinical, and experimental studies have suggested that excessive exposure to estrogens and xenoestrogens during fetal and neonatal development may induce testicular developmental disorders, leading to alterations in the adult male fertility. Recently, we have clearly demonstrated that fetal and neonatal testes are very sensitive to estrogens, as the inactivation of estrogen receptor $\alpha$ increases steroidogenesis and the inactivation of estrogen receptor $\beta$ enhances development of the germ cell lineage in the male.

Reproduction (2006) 132 527-538
\end{abstract}

\section{Alterations in male reproductive function}

Changes in the environment and their consequences for male reproductive function have been of major concern for the past 20 years.

Alterations in male reproduction were first observed in wild animals, in studies reporting the effects of accidental exposure of estrogenic chemicals on wildlife in the natural environment. These changes in male reproductive function vary from very subtle changes to permanent alterations, such as feminization or changes in reproductive behavior (Vos et al. 2000). Guillette et al. (1994) studied the male reproductive functions of alligators in two lakes in Florida. These two lakes are located very close to each other geographically, excluding the possibility of climate-based bias in these studies. They found that adult male alligators in Apopka Lake, which was polluted with agricultural waste and experienced a major chemical spill in 1980, had lower testosterone levels and presented micropenis and disorganized testes (Guillette et al. 1994, Guillette \& Guillette 1996). A key part of this story is that no chemicals could be detected in the water of the apparently contaminated lake and thus the alligators were being exposed simply by being at the top of the food chain. Other documented disruptions or alterations of reproductive activity and physiology have been correlated with exposure of contaminants in fish, amphibians, reptiles, birds, and mammals (examples in Table 1; for detailed review, see Vos et al. 2000, Edwards et al. 2006). Most of the reported effects on wildlife have been done on aquatic food chain organism making the causal link a direct or an indirect effect of pollutants hard to do.

In humans, there is increasing evidence that the birth sex ratio is altered in areas close to industry and exposed to environmental and industrial chemicals. The findings of the very recent report on the Aamjiwnaang First Nation community in Canada are striking (Mackenzie et al. 2005), i.e. the proportion of male live births in this community has been decreasing continually from 1990 to 2003, the sex ratio (number of male births/total number of births) reaching only 0.3 . The epidemiologic data have also shown an increase in human male reproductive function disorder over the past 50 years, with the suggestion of a relation with the increase in the amounts of endocrine disruptors in the environment. Testicular cancer, which is the most prevalent cancer in young men, has steadily 
Table 1 Effect of xenoestrogens on male reproduction in wildlife.

\begin{tabular}{|c|c|c|c|c|c|}
\hline & Species & Country & Pollutant & Effects & References \\
\hline \multirow[t]{3}{*}{ Mammals } & Panther & Florida, USA & Mercury, $p, p^{\prime} D D E, P C B$ & $\begin{array}{l}\text { Cryptochidism sperm count and } \\
\text { motility }\end{array}$ & $\begin{array}{l}\text { Facemire et al. } \\
\text { (1995) } \\
\text { Mansfield \& Land } \\
(2002)\end{array}$ \\
\hline & Beluga whales & Quebec, Canada & PCB & Hermaphroditism & $\begin{array}{l}\text { De Guise et al. } \\
\text { (1994) }\end{array}$ \\
\hline & Polar bear & Svalbard, Russia & Organochlorine, PCB & Testosterone level & Oskam et al. (2003) \\
\hline Birds & Western gull & California, USA & DDT, methoxychlor & $\begin{array}{l}\text { Feminization (ovotestis, persistant } \\
\text { mullerian duct) }\end{array}$ & $\begin{array}{l}\text { Fry \& Toone (1981), } \\
\text { Fry (1995) }\end{array}$ \\
\hline \multirow[t]{2}{*}{ Reptiles } & Sanpping turtles & Ontario, Canada & Organochlorine & Feminization & $\begin{array}{l}\text { De Solla et al. } \\
\text { (1998) }\end{array}$ \\
\hline & Alligator & Florida, USA & $P, p^{\prime} D D E$ & $\begin{array}{l}\text { Abnormal gonadal development and } \\
\text { steroidogenesis penis size }\end{array}$ & $\begin{array}{l}\text { Guillette et al. } \\
\text { (1994), Guillette \& } \\
\text { Guillette (1996) }\end{array}$ \\
\hline Amphibians & Leopard frog & Diiferent sites, USA & Atrazine & Gonadal dysgenesis hermaphroditism & Hayes et al. (2003) \\
\hline \multirow[t]{3}{*}{ Fish } & Roach fish & Leicestershire, UK & Endocrine disruptors & Intersex sperm count/motility & Jobling et al. (2002) \\
\hline & Spottail shiner & Quebec, Canada & Estrogenic compounds & $\begin{array}{l}\text { Intersex spermatogenesis impairment } \\
\text { sperm count/motility }\end{array}$ & $\begin{array}{l}\text { Aravindakshan } \\
\text { et al. (2004) }\end{array}$ \\
\hline & Catfish & $\begin{array}{l}\text { Gauteng, South } \\
\text { Africa }\end{array}$ & p-nonylphenol & Intersex & $\begin{array}{l}\text { Barnhoorn et al. } \\
\text { (2004) }\end{array}$ \\
\hline
\end{tabular}

increased in all countries studied, rising from 3.4\% in 1973 to $5.5 \%$ in 1997 in North America (Toppari 2002). Hypospadias and cryptorchidism also increased from 0.2 and $2 \%$ respectively in 1970 to 0.38 and $3.5 \%$ respectively in 1991 (Toppari 2002). Finally, the sperm count decline have been controversial but large-scale prospective studies using standardized methodologies have shown a decline from 170 to 70 million spermatozoa per milliliter between 1940 and 1990 in Europe (Auger et al. 1995, Sharpe \& Irvine 2004). There are grounds for linking these four disorders. For example, a comparative study in European countries showed that the incidence of each of these four abnormalities (sperm count decline, testicular cancer, hypospadias, and cryptorchidism) was maximal in Denmark and minimal in Finland (Virtanen et al. 2005). Moreover, having a history of cryptorchidism increases the risk of other three disorders (Kaleva et al. 2005) by a factor of 3-17 in the case of testicular cancer (Davenport 1997). Similarly, hypospadias increases the chances of developing testicular cancer (Sharpe \& Irvine 2004) and oligospermia is frequently observed in men, who go on to develop testicular cancer (Moller \& Skakkebaek 1999, Skakkebaek et al. 2001). Therefore, it has been suggested that these four alterations are symptoms of a single syndrome, the testicular dysgenesis syndrome (TDS; Skakkebaek et al. 2001, Skakkebaek \& Jorgensen 2005).

\section{These abnormalities first arise during fetal development}

The testes begin to carry out their two major functions (gametogenesis and steroidogenesis) during fetal development. Sertoli cells are the first to differentiate. From 12 days postconception $(\mathrm{dpc})$ in the mouse, 13.5 $\mathrm{dpc}$ in the rat, and 42-45 dpc in human, they surround the germ cells to form the seminiferous cords. Sertoli cells divide actively until puberty, remaining quiescent thereafter. Primordial germ cells arise from the epiblast and migrate from the extra-embryonic mesoderm to colonize the genital ridge. The germ cells are named gonocytes once they reach the gonad, in which they proliferate until fetal day 15.5 in the mouse and fetal day 17.5 in the rat. The gonocytes (Fig. 1A) then enter a quiescent period during which their number does not change. This period extends to birth in the mouse and postnatal day 3 in the rat, when mitosis resumes and gonocytes differentiate into gonia (Olaso \& Habert 2000). Fetal Leydig cells (Fig. 1B) differentiate soon after Sertoli cells and produce the testosterone and insulin-like factor 3 (Insl3) necessary for masculinization of the fetus (Habert et al. 2001, Kubota et al. 2002).

It is currently thought that TDS is probably caused by changes in the development of the fetal testis (Skakkebaek et al. 2001) because the origins of all four characteristics of TDS can be traced to fetal development. Hypospadias results from a defect in the androgen production or action during fetal development. Cryptorchidism results from the abnormalities in the

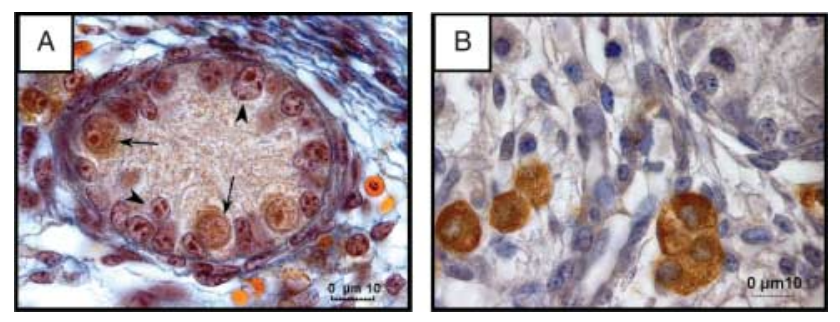

Figure 1 Histological aspect of the mouse neonatal testis observed 2 days after birth. (A) Seminiferous cord after coloration by Tushmann's blue. Arrows indicate the gonocytes, arrowhead indicates the Sertoli cells from Delbes et al. (2004). (B) Leydig cells, located in interstitial compartment, after immunohistochemical labeling of $3 \beta$-hydroxysteroid dehydrogenase ( $3 \beta \mathrm{HSD}$ ); from Delbes et al. (2005). 
production or activity of Insl3 or the androgens regulating the transabdominal and transinguinal descent respectively of the testes (Kubota et al. 2002). The etiology of testicular cancer remains unclear, but there is considerable evidence to suggest that it originates early in development (Skakkebaek et al. 2001) when gonocytes would normally have differentiated into spermatogonia. Carcinoma in situ (CIS) is a local malignant lesion that precedes testicular cancer (seminomas and nonseminomas; Skakkebaek et al. 1981). CIS cells closely resemble fetal germ cells in terms of morphology and immunohistological markers (c-kit, alkaline phosphatase, etc; Rajpert-De Meyts et al. 1998). Moreover, CIS has been reported in only a few-months-old boys (Skakkebaek et al. 2001). Finally, sperm counts may have decreased for multiple reasons as the regulation of spermatogenesis remains poorly understood, but is known to involve complex endocrine, intratesticular, and intracellular regulation processes. The stock of gonocytes is determined during fetal development and takes part in determining the number of germ stem cells present in adulthood, since experimentally induced decreases in the number of gonocytes during fetal development lead to decreases in sperm count in adulthood (Moreno et al. 2001). Similar results are obtained if the number of Sertoli cells is reduced during perinatal life (Orth et al. 1988). Thus, adult sperm production depends partly on the fetal gametogenesis and partly on the capacity of gonocytes to differentiate into gonia.

The hypothesis of fetal origin of TDS is also supported by clinical and experimental reports.

The major clinical data concern the boys born of women treated during their pregnancy with diethylstilbestrol (DES), a very potent estrogen agonist, from 1950 to 1970 . Some studies have reported alterations in sperm quality and a higher incidence of genital malformations, cryptorchidism, and testicular cancer than for the control population (Glaze 1984, Strohsnitter et al. 2001), whereas others found no such change (Wilcox et al. 1995). These discrepancies may be due to differences in the period of treatment during pregnancy, suggesting that there may be a specific period of sensitivity to xenoestrogens in the testis. A recent analysis of these epidemiological studies by Storgaard et al. (2006) pointed out that DES seems to have a negative effect on sperm count only if administered at high dose during the first semester of pregnancy.

Another clinical argument concerns the recent demonstration that phthalates (founds in cosmetics, paint, and PVC) have negative effects on human male reproductive tract development (Swan et al. 2005). Maternal urinary phthalate concentration during the pregnancy is inversely correlated with anogenital distance at birth. This finding is particularly important as it provides the first demonstration of negative effects of xenobiotics at environmental concentrations.
Experimentally, the following two approaches have been used in rodents to determine the effects of exposure to exogenous estrogens during fetal and neonatal development on male reproductive functions

In vitro studies in the rat are based on organ cultures and primary cell cultures (Table 2). These techniques are useful to detect short-term effects and have shown that estrogenic molecules (DES, $17 \beta$-estradiol, etc.) may alter cord formation early in testis development (Cupp \& Skinner 2001, Lassurguere et al. 2003) and disrupt the development of germ cells, Leydig cells, and Sertoli cells. Our recent unpublished results evidenced that rat testicular cells are more sensitive to estrogens during the early fetal period (Delbès G, Duquenne C, Habert R \& Levacher $\mathrm{C}$ unpublished observation, Table 2).

In vivo, rodents can be treated with exogenous estrogens during fetal and neonatal development by injection, gavage, or via their drinking water. Numerous reports based on this experimental design have been published in recent years (Tables 3 and 4). The effects are observed in the short (before puberty; Table 3) or the long term (in adulthood; Table 4). Differences between treatment protocols (route of administration, age at treatment, duration, and time of treatment, etc.) and animal strains (rats: Wistar, Sprague-Dawley, etc. and mice: $\mathrm{C} 57 \mathrm{BI} / 6$, Swiss, NMRI, etc.) make it hard to draw a general process of effect. Indeed, sensitivity to estrogenic chemicals is known to depend on the species and the strain of animal (Spearow \& Barkley 2001). However, all these studies suggest that exposure to high doses of exogenous estrogens during gestation can induce all the symptoms of TDS. These effects are dose-dependent and two studies (Atanassova et al. 2000, Fielden et al. 2003) in which low doses were administered reported no alterations. Furthermore, the alterations observed depend on the molecule tested, DES being the most potent, consistent with its three or four times higher affinity for the estrogen receptor than estradiol itself (Kuiper et al. 1997), and phytoestrogens the weakest (Fielden et al. 2003, Thuillier et al. 2003, Adachi et al. 2004). The timing of exposure is also an important criterion, with early exposure being the most deleterious, due to very rapid effects on testicular histology and functions and the probable induction of irreversible effects.

It is important to note that all these studies focused on a single estrogenic compound while in reality, individuals are exposed to a cocktail of chemicals that could lead to more potent effects.

\section{Estrogen receptors in the fetal testis}

To date, two estrogen receptors have been described, ER $\alpha$ (Green et al. 1986) and ER $\beta$ (Kuiper et al. 1996). Both belong to the steroid nuclear receptor superfamily and regulate gene expression. $E R \alpha$ and $E R \beta$ are encoded by two different genes located on different chromosomes (10 and 12 respectively in mouse, 1 and 6 in rat, and 6 and 
Table 2 In vitro effects of estrogen treatment on fetal and neonatal rat testis or testicular cells.

\begin{tabular}{|c|c|c|c|c|}
\hline Protocol & Age & Treatment & Effects & References \\
\hline \multirow[t]{2}{*}{ Organ culture } & $\begin{array}{l}13.5 \mathrm{dpc} \\
14.5 \mathrm{dpc}\end{array}$ & $\begin{array}{l}\text { 17 } \beta \text {-estradiol }(4 \mu \mathrm{M}-72 \mathrm{~h}) \\
\text { DES }(4 \mu \mathrm{M}-72 \mathrm{~h})\end{array}$ & $\begin{array}{l}\text { Cord formation alteration } \\
\downarrow \text { Number of gonocytes } \\
\downarrow \text { Number of Sertoli cells } \\
\downarrow \text { Number of Leydig cells } \\
\downarrow \text { Testosterone secretion }\end{array}$ & $\begin{array}{l}\text { Lassurguere et al. (2003) } \\
\text { Cupp et al. (2001) }\end{array}$ \\
\hline & $\begin{array}{l}20.5 \mathrm{dpc} \\
3 \mathrm{dpp}\end{array}$ & $\begin{array}{l}\text { 17 } \beta \text {-estradiol }(4 \mu \mathrm{M}-72 \mathrm{~h}) \\
\text { DES }(4 \mu \mathrm{M}-72 \mathrm{~h}) \\
17 \beta \text {-estradiol }(4 \mu \mathrm{M}-72 \mathrm{~h}) \\
\text { DES }(4 \mu \mathrm{M}-72 \mathrm{~h})\end{array}$ & $\begin{array}{l}\text { No modification of testosterone secretion } \\
\text { No modification of the number of gonocytes }\end{array}$ & $\begin{array}{l}\text { Delbès et al. } \\
\text { (unpublished data) }\end{array}$ \\
\hline \multirow[t]{3}{*}{ Leydig cell culture } & $21.5 \mathrm{dpc}$ & $17 \beta$-estradiol $(2 \mu \mathrm{M}-72 \mathrm{~h})$ & $\downarrow$ Testosterone secretion & Tsai-Morris et al. (1986) \\
\hline & $\begin{array}{l}16.5 \mathrm{dpc} \\
20.5 \mathrm{dpc}\end{array}$ & $\begin{array}{l}\text { 17 } \beta \text {-estradiol }(0.01-1 \mu \mathrm{M}-48 \mathrm{~h}) \\
\text { DES }(0.01-1 \mu \mathrm{M}-48 \mathrm{~h})\end{array}$ & $\downarrow$ Testosterone secretion & $\begin{array}{l}\text { Delbès et al. } \\
\text { (unpublished data) }\end{array}$ \\
\hline & $6-7 \mathrm{dpp}$ & $\begin{array}{l}\text { 17 } \beta \text {-estradiol }(1 \mu \mathrm{M}-24 \mathrm{~h}) \\
\text { Octylphenol }(24 \mathrm{~h})\end{array}$ & $\begin{array}{l}\text { No modification of testosterone secretion } \\
1-10 \mathrm{nM} \text { : testosterone secretion } \\
100-200 \mathrm{nM}: \downarrow \text { testosterone secretion }\end{array}$ & Murono et al. (1999) \\
\hline $\begin{array}{l}\text { Purified gonocyte } \\
\text { culture }\end{array}$ & $3 \mathrm{dpp}$ & $\begin{array}{l}17 \beta \text {-estradiol }(1 \mu \mathrm{M}-20 \mathrm{~h}) \\
17 \beta \text {-estradiol }(0.1 \text { and } 10 \mu \mathrm{M}-20 \mathrm{~h})\end{array}$ & $\begin{array}{l}\uparrow \text { Gonocyte proliferation } \\
\text { No effect }\end{array}$ & Li et al. (1997) \\
\hline $\begin{array}{l}\text { Coculture sertoli } \\
\text { cells/gonocytes }\end{array}$ & $\begin{array}{l}16.5 \mathrm{dpc} \\
3 \mathrm{dpp}\end{array}$ & $\begin{array}{l}\text { DES }(1 \mu \mathrm{M}-5 \text { days }) \\
17 \beta \text {-estradiol }(1 \mu \mathrm{M}-5 \text { days })\end{array}$ & $\downarrow$ Number of gonocytes only at $16.5 \mathrm{dpc}$ & $\begin{array}{l}\text { Delbès et al. } \\
\text { (unpublished data) }\end{array}$ \\
\hline
\end{tabular}

$\mathrm{dpc}$, day post-conception; dpp, day post-partum; DES, diethystilbestrol.

14 in humans). Numerous human isoforms are generated due to alternative splicing of the $\mathrm{C}$-terminal region (Hirata et al. 2003). Similar isoforms have also been described in rodents (Chu \& Fuller 1997, Lu et al. 1998). No biological function has yet been reported for the truncated ER $\alpha$ protein, but many physiological implications of the ER $\beta$ isoforms are currently being investigated.

The expression of these isoforms in the adult reproductive tract has recently been reviewed (Akingbemi 2005, Saunders 2005). ER $\alpha$ and ER $\beta$ are present in the fetal testis very early in development and their distribution in various types of testicular cell has been extensively studied in mammals. Immunohistochemical data have shown that ER $\alpha$ protein is present in the undifferentiated gonad as early as $10.5 \mathrm{dpc}$ in the mouse (Greco et al. 1992) and is localized in the fetal Leydig cells until birth in rodents review in O'Donnell et al. (2001). Only one study has shown some staining in the seminiferous cords (Greco et al. 1992). ERß mRNA is detected in the testis as early as $14 \mathrm{dpc}$ in the mouse (Jefferson et al. 2000) and is present primarily in the gonocytes, and also in the Sertoli and Leydig cells, as early as $16 \mathrm{dpc}$ in the rat (Van Pelt et al. 1999). $E R \beta$ protein is present at $16 \mathrm{dpc}$ in three main types of testicular cells in the rat but is found exclusively in the gonocytes in the mouse (Saunders et al. 1998, Jefferson et al. 2000). However, in a recent study, ER $\beta$ was not detected in isolated Sertoli cells from 3-days-old rats (Wang et al. 2004). Immunohistochemical analysis has shown that in humans, ER $\beta$ is not present in the testis but $E R \beta$ is expressed in germ cells, Sertoli cells, and Leydig cells (Saunders et al. 2001).
Other rapid effects of estrogen have been described that cannot be accounted for by the 'classical' genomic action of estrogens. Some new 'non-classical' estrogen pathways involving a membrane receptor for estrogen capable of activating numerous intracellular pathways (G protein, kinases, etc.) have been proposed (Luconi et al. 2002). A G protein-coupled estrogen receptor was recently identified in a breast cancer cell line and shown to be present in the adult testis (Thomas et al. 2005). Studies of the effects of estrogen on the fetal and neonatal testis are still limited to the classical pathway, but further investigation of the involvement of other estrogen receptors is required.

\section{The role of endogenous estrogens in fetal and neonatal testicular development}

It is now widely accepted that estrogens play vital role in the control of reproductive function in the adult male reviewed in Carreau et al. (2003) and Akingbemi (2005). Few human cases of spontaneous mutation in the estrogen pathway have been described: one homozygous mutation of the ER $\alpha$ gene (Smith et al. 1994) and six cases of aromatase deficiency (Morishima et al. 1995, Carani et al. 1997, Deladoey et al. 1999, Herrmann et al. 2002, Maffei et al. 2004, Mittre Herve et al. 2004). These patients mostly display skeletal disorders, as they are very tall and continue to grow in adulthood. They display no masculinization disorders, but present high levels of testosterone, luteinizing 
Table 3 Short-term effects of in vivo treatment with estrogenic coumpounds during fetal and neonatal life on testicular development in rodents.

\begin{tabular}{|c|c|c|c|c|c|}
\hline Protocol & Treatment regimen & Treatment age & Observation age & Observations & References \\
\hline Gavage (Jc1:MCR mice) & $\begin{array}{l}\text { Ethinyl estradiol }(0.02-2 \mathrm{mg} / \mathrm{kg} \\
\text { per day) }\end{array}$ & $11-17 \mathrm{dpc}$ & $18 \mathrm{dpc}$ & $\begin{array}{l}\text { Ootestis, cryptorchidism } \\
\uparrow \text { Number of gonocytes } \\
\downarrow \text { Number of Sertoli cells } \\
\text { Leydig cell hyperplasia }\end{array}$ & $\begin{array}{l}\text { Yasuda et al. (1985a), } \\
\text { Yasuda et al. (1985b) }\end{array}$ \\
\hline Subcutaneous injection (NMRI mice) & $\begin{array}{l}\alpha \text {-Zeranol }(150 \mu \mathrm{g} / \mathrm{kg} \text { per day }) \\
\text { DES }(150 \mu \mathrm{g} / \mathrm{kg} \text { per day })^{\mathrm{a}}\end{array}$ & $9-10 \mathrm{dpc}$ & $12-18 \mathrm{dpc}$ & $\begin{array}{l}\text { Changes to gonocyte differentiation } \\
\text { Leydig cell hyperplasia } \\
\text { Testicular descent delay }\end{array}$ & Perez-Martinez et al. (1996) \\
\hline Subcutaneous injection (rat) & $\begin{array}{l}\text { OP }(600 \mathrm{mg} / \mathrm{kg} \text { per day }) \\
\text { DES }(500 \mu \mathrm{g} / \mathrm{kg} \text { per day })\end{array}$ & 11 and $15 \mathrm{dpc}$ & $17 \mathrm{dpc}$ & $\begin{array}{l}\downarrow \text { SF-1 mRNA in testis } \\
\downarrow \text { SF-1 protein in Sertoli cells }\end{array}$ & Majdic et al. (1997) \\
\hline Subcutaneous injection (Wistar rat) & $\begin{array}{l}\text { OP (100-600 mg/kg per day) } \\
\text { DES (100-500 } \mu \mathrm{g} / \mathrm{kg} \text { per day) } \\
\text { BPA (0.5 mg/animal per day) }\end{array}$ & $\begin{array}{l}11 \text { and } 15 \mathrm{dpc} \\
2,4,6,8,10,12 \mathrm{dpp}\end{array}$ & $\begin{array}{l}17 \mathrm{dpc} \\
18 \mathrm{dpp}\end{array}$ & $\begin{array}{l}\text { No histological difference } \\
\text { No modification of Leydig cell number } \\
\downarrow \text { P450c } 17 \text { and SF- } 1 \text { protein levels } \\
\downarrow \text { Testis weight } \\
\downarrow \text { FSH } \beta \text { and inhibin } \alpha \text { levels }\end{array}$ & Saunders et al. (1997) \\
\hline Gavage (Sprague-Dawley rat) & $\begin{array}{l}\text { DES }(0.01-2 \mu \mathrm{g} / \mathrm{kg} \text { per day }) \\
\text { BPA }(0.1-200 \mathrm{mg} / \mathrm{kg} \text { per day }) \\
\text { Genistein }(0.1-10 \mathrm{mg} / \mathrm{kg} \text { per day }) \\
\text { Coumestrol }(1-100 \mathrm{mg} / \mathrm{kg} \text { per day })\end{array}$ & $14-21 \mathrm{dpc}$ & $0-3 \mathrm{dpp}$ & $\begin{array}{l}\uparrow \text { In hsp90 levels in gonocytes } \\
\uparrow \text { PDGFR }\end{array}$ & $\begin{array}{l}\text { Thuillier et al. (2003), } \\
\text { Wang et al. (2004) }\end{array}$ \\
\hline $\begin{array}{l}\text { Subcutaneous injection } \\
\text { (Sprague-Dawley rat) }\end{array}$ & $\begin{array}{l}\text { DES }(0.01-0.2 \mathrm{mg} / \mathrm{kg} \text { per day }) \\
\text { OP }(0.1-100 \mathrm{mg} / \mathrm{kg} \text { per day }) \\
\text { BPA (1-100 mg/kg per day) }\end{array}$ & $13,15,17 \mathrm{dpc}$ & $19 \mathrm{dpc}$ & $\begin{array}{l}\text { Alkylphenols have no effect } \\
\text { Dose-dependent decrease in testosterone } \\
\text { secretion in response to DES }\end{array}$ & Haavisto et al. (2003) \\
\hline Subcutaneous injection (rat) & Estradiol benzoate $(500 \mu \mathrm{g})$ & $1 \mathrm{dpp}$ & $10 \mathrm{dpp}$ & $\downarrow$ Intratesticular testosterone content & Bellido et al. (1990) \\
\hline Subcutaneous injection (Swiss mice) & $17 \beta$-estradiol $(10 \mu \mathrm{g} /$ day $)$ & $1-9 \mathrm{dpp}$ & $10 \mathrm{dpp}$ & $\downarrow$ Circulating testosterone level & Cooke and Eroschenko (1990) \\
\hline
\end{tabular}

DES, Diethylstilbestrol; OP, 4-octylphenol; BPA, Bisphenol A 


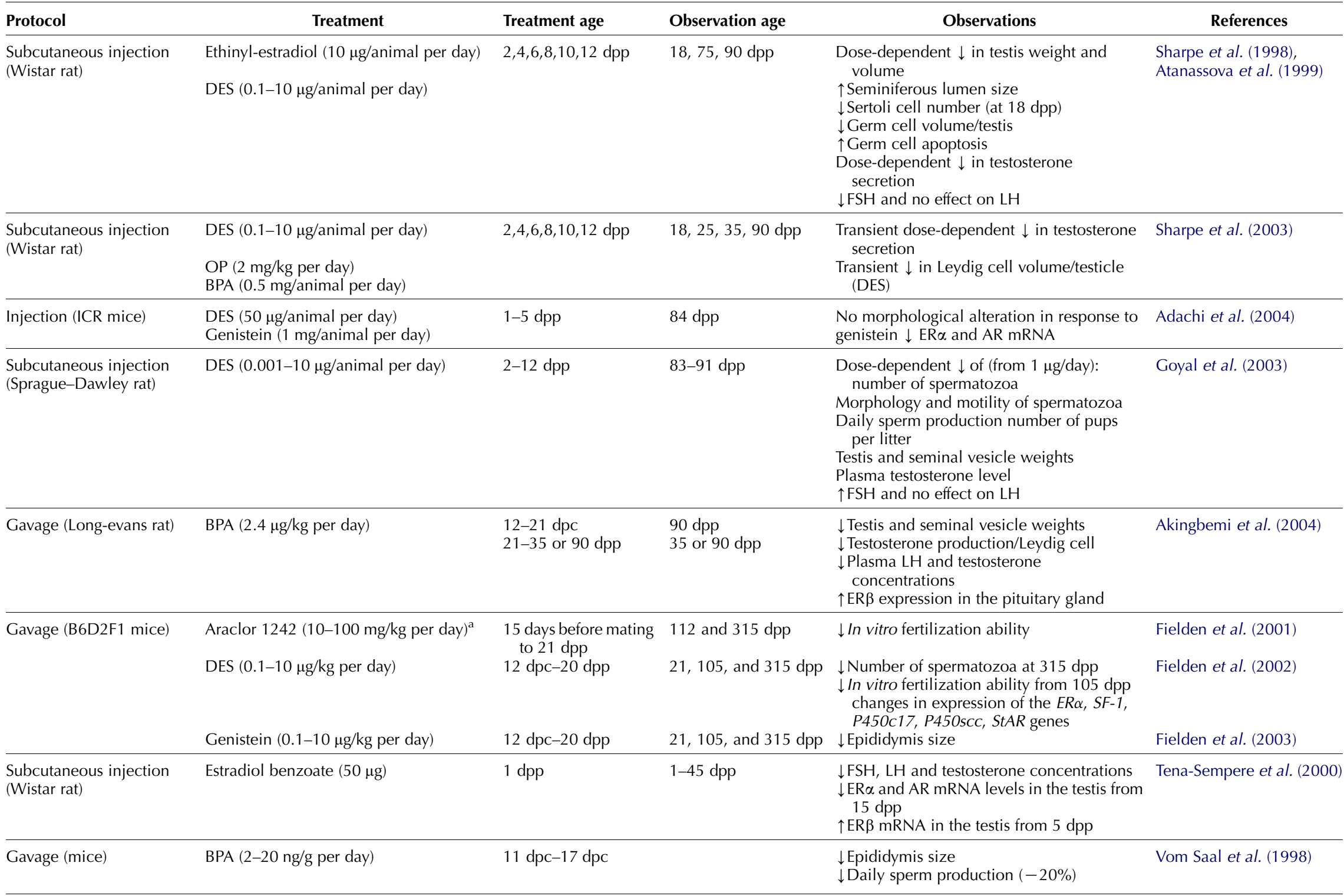


hormone ( $\mathrm{LH})$, and follicle-stimulating hormone (FSH). These men also have low sperm viability (Smith et al. 1994), number, and motility (Herrmann et al. 2002) with bilateral cryptorchidism in one case (Maffei et al. 2004).

The development of transgenic mouse models has improved our understanding of the role of estrogens in male reproduction. Male mice with inactivated estrogen receptor (ER $\alpha K O, E R \beta K O$ and $E R \alpha \beta K O)$ or aromatase (ArKO) genes show reproductive disorders. ER $\alpha$ KO and ArKO mice are sterile due to epididymal reabsorption fluid deficiency in ERaKO mice and spermatogenesis disorders in ArKO mice reviewed in $\mathrm{O}^{\prime}$ Donnell et al. (2001). Excess estrogens or xenoestrogens alter male reproductive function, but these data show that estrogen deficiency may also have negative effect, raising the possibility that endogenous estrogens are essential for the maintenance of male fertility.

We investigated the role of endogenous estrogens during fetal and neonatal testicular development by analyzing testis development in mice inactivated for ER $\alpha K O$ and ERßKO (Delbes et al. 2004, 2005). Inactivation of the $E R \beta$ gene induced a $50 \%$ increase in the number of gonocytes observed 2 and 6 days after birth (Fig. 2) due to an increase in the proliferation and a decrease in the apoptosis of these cells, with no change in Sertoli cell number or Leydig cell number $E R \alpha$ gene did not modify the number of gonocytes; it increased testosterone production from the earliest stage studied $(13.5 \mathrm{dpc}$, i.e. just 2 days after the first fetal Leydig cells start to differentiate; Fig. 3). We also found that the negative effect of estrogens on fetal and neonatal steroidogenesis did not depend on the hypothalomo-pituitary axis (Delbes et al. 2005), in contrast to reports of adults (Akingbemi et al. 2003). The activity of each fetal Leydig cell is increased by inactivation of the $E R \alpha$ gene as shown by the hypertrophy of these cells and their higher levels of
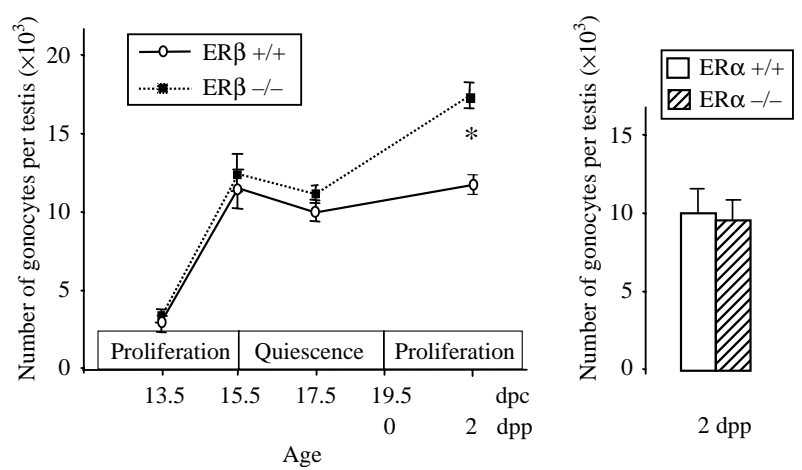

Figure 2 Number of gonocytes per testis during fetal and neonatal life after $E R \beta$ or $E R \alpha$ gene inactivation. Proliferation and quiescent periods of the gonocytes throughout the considered developmental period are indicated. Gonocytes were counted on histological testis sections from $13.5,15.5,17.5 \mathrm{dpc}$, and $2 \mathrm{dpp}$ animals. Values are mean \pm s.E.M. of $4-13$ animals. ${ }^{*} P<0.001$ versus wild-type in Student's $t$-test. From Delbes et al. (2004).
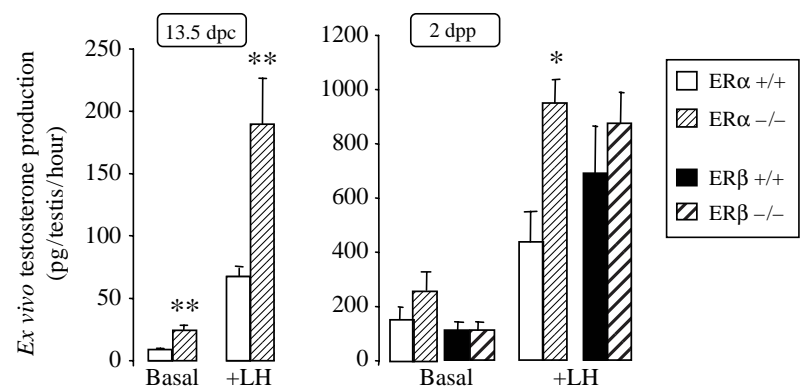

Figure 3 Production of testosterone by the fetal and neonatal mouse testis after $E R \beta$ or $E R \alpha$ gene inactivation. Testes were collected on day $13.5(13.5 \mathrm{dpc})$ of gestation and on postnatal day 2 (2 dpp) and cultured on floating Millipore filters for $3 \mathrm{~h}$ in the presence $(+\mathrm{LH})$ or the absence (basal) of $100 \mathrm{ng} / \mathrm{ml}$ ovine LH. The testosterone secreted in the medium was measured by radioimmunoassay. Values are mean \pm s.E.M. of $7-19$ fetuses. ${ }^{*} P<0.01$ and ${ }^{* *} P<0.001$ versus wild-type in Student's $t$-test. From Delbes et al. (2005).

StAR, P450scc, and P450 c17 mRNA. These data clearly show that endogenous estrogens inhibit testicular development and function during fetal and neonatal life. ER $\beta$ is involved in the control of gametogenesis, consistent with its location within the seminiferous cords, whereas ER $\alpha$ is present in the fetal Leydig cells and regulates steroidogenesis.

\section{Origin and levels of estrogens acting on the developing testis}

The question of the origin and level of endogenous estrogens acting on the developing testis during fetal and neonatal development is of prime importance, given the potential negative effect of exogenous estrogens and the need to improve our understanding of periods of sensitivity. Maternal plasma estrogen concentration peaks around gestational day 18. We showed that in $\mathrm{C} 57 \mathrm{Bl} / 6$ mice, plasma $17 \beta$-estradiol concentration is $0.19 \mathrm{nM}$ at $13.5 \mathrm{dpc}, 0.43 \mathrm{nM}$ at $15.5 \mathrm{dpc}$, and $0.49 \mathrm{nM}$ at $17.5 \mathrm{dpc}$ (unpublished data), consistent with the previous reports (Barkley et al. 1979, Mahendroo et al. 1997). The only data dealing with intratesticular estradiol concentration in the fetal and neonatal mouse testis presently available is our measurement of a concentration equal to $4 \mathrm{nM}$ at $2 \mathrm{dpp}$ (Delbes et al. 2004). In the rat, intratesticular concentration of $17 \beta$-estradiol is 0.55 and $0.34 \mathrm{nM}$ at 18.5 and $20.5 \mathrm{dpc}$ respectively and $0.36 \mathrm{nM}$ in the fetal plasma at both ages (Habert \& Picon 1984). Because of the presence of binding proteins in the plasma, these results suggest a production of estradiol by the testis.

Only one previous study reported the detection of aromatase mRNA in mouse fetal testis from $17.5 \mathrm{dpc}$ onwards (Greco \& Payne 1994). It had been suggested that expression of the aromatase gene in the fetal testis is 
repressed by the product of Sry gene (Haqq et al. 1993), from embryonic days 12 to 16 . We recently demonstrated the importance of aromatase activity by using organotypic culture. Addition of $\mathrm{ICl} 182.780$, an antagonist of $E R$, to the culture medium increased the testosterone production by $20.5 \mathrm{dpc}$ fetal rat testis, suggesting that estrogens produced by the cultured testis is sufficient to partially inhibit steroidogenesis (Delbès et al. unpublished data). On the contrary, ICI 182.780 did not change the testosterone production of $14.5 \mathrm{dpc}$ testis when aromatase is probably not yet expressed (Lassurguere et al. 2003).

During late fetal life, aromatase is probably expressed by Sertoli cells at this stage in the rat as estrogens production is stimulated by FSH (Weniger \& Zeis 1988, Rouiller-Fabre et al. 1998). Aromatase activity is weaker in the fetal Leydig cells than in adult Leydig cells (Saez 1994). Thus, the main source of estrogens is the Sertoli cells during fetal and neonatal life, whereas it is the Leydig cells in the adult. Furthermore, aromatase has been found in adult germ cells (Lambard et al. 2005), but no study has investigated whether aromatase is expressed in the gonocytes. This issue is of importance for the determination of the local concentration of estrogens in the target cell.

\section{Remaining debates}

Experimental data have shown that estrogens may have irreversible negative effects on testicular development and masculinization during fetal and neonatal life, consistent with the current hypothesis concerning the origin of TDS. However, controversy persists concerning the possible causal link between estrogen exposure during fetal and neonatal development and TDS (Storgaard et al. 2006). Recently, new data showed that polymorphism and lifestyle changes may also be responsible for male infertility (Aschim et al. 2005, Safe 2005).

We provided the first demonstration that endogenous estrogens physiologically regulate testicular development in a negative manner during fetal and neonatal life by controlling the two main functions of the testis, gametogenesis and steroidogenesis. As explained previously, changes in the establishment of the germ cell lineage may induce testicular cancer and abnormal sperm production. Furthermore, if testosterone secretion is regulated by estrogens, then estrogens control masculinization of the genital tract and testicular descent. This model is consistent with Sharpe \& Skakkebaeck's (1993) hypothesis. Nevertheless, the link between abnormalities at birth and their real consequences for adult fertility is very weak, as the regulation of spermatogenesis changes considerably during puberty. Estrogen deficiency has positive effects during fetal development (increasing number of germ cells and steroidogenic activity) and negative effects in adulthood, with affected mice becoming infertile. Determination of the real impact of estrogen deficiency during gestation on adult fertility would require studies of transiently transgenic mice, in which the expression of estrogen receptor genes was repressed only during this period of life.

Each estrogen receptor is involved in regulating one particular function, $E R \beta$ being involved in gametogenesis and $E R \alpha$ in steroidogenesis processes. These precise mechanisms of action of estrogens in the fetal testis could help us to anticipate the effects of different estrogenic compounds depending on their affinity for each receptor. For example, genistein, which has a stronger affinity for ER $\beta$ than ER $\alpha$ (Kuiper et al. 1997), would be expected to have a stronger effect on germ cells than that on steroidogenesis.

The existence of periods of development during which the testis is particularly sensitive to estrogens is strongly suggested by epidemiologic study of men exposed in utero to DES. These sensitive periods may vary depending on the susceptibility of the individual, as reported for the different strains of experimental animals (Spearow \& Barkley 2001). We have shown in organ culture that exogenous estrogens inhibit gametogenesis only during fetal life $(14.5 \mathrm{dpc})$ in the rat, whereas studies in ERßKO mice showed inhibition to occur later. It is unclear whether this difference is due to the difference in species (rat versus mice) or dose (addition of estrogens versus deficiency). Studies of the sensitivity of the human fetal testis would provide important new information, particularly as human testes differ from rodent testes in not expressing $\mathrm{ER} \alpha$ and in containing numerous ER $\beta$ mRNA variants (Moore et al. 1998).

Despite the accumulation of experimental data, the question of a possible direct effect of the increase in xenoestrogen levels in the environment on male fertility remains unanswered. With the exception of the report by Swan et al. (2005), studies using phytoestrogens or DES (Atanassova et al. 2000, Fielden et al. 2003) at low doses or at doses equivalent to human dietary exposure levels have reported no deleterious effect (Table 3). This has led some authors to conclude that endocrine disruptors do not reach sufficiently high concentrations in the body to have a deleterious effect on human health. However, individual can be exposed to a combination of chemicals with different activities (estrogenic, anti-androogenic, etc.). Moreover, the lipophilic characteristics of these molecules may result in their accumulation in fat tissues and these molecules may exert their effects by acting in combination. The developing fetus may be subjected to higher levels of xenoestrogens as maternal lipid stores are metabolized during pregnancy. Therefore, this raises the question of what is a physiologically relevant concentration of xenoestrogens.

Finally, a recent study highlighted the importance of this problem by demonstrating that rats descended from a great-grandfather exposed to high levels of endocrine disruptors during fetal development have low levels of sperm production (Anway et al. 2005, 2006). Thus, 
changes in fetal testis development are observed not only in the contaminated individual during adulthood, but are also transmitted to subsequent generations by an undetermined epigenetic mechanism. This would have potentially major implications in terms of evolutionary biology and disease etiology and provides support for health care and environmental preventive action with respect to endocrine disruptors.

\section{Acknowledgements}

We thank C Duquenne for useful technical assistance, Prof P Chambon and A Krust (IGBMC, Illkirch, France) for providing transgenic mice, A Gouret for expert secretarial assistance and C Joubert, C Chauveau, S Leblay, and V Neuville (CEA, Fontenay-aux-Roses, France) for caring the animals. This work was partly supported by a grant from INSERM project 'Environnement et Santé' (2004-2006) and a grant from Ministère de I'Ecologie et du Développement Durable, Programme National de Recherche sur les Perturbateurs Endocriniens (2005-2007). G Delbès held a fellowship from the Ministère de l'Education Nationale de la Recherche et de la Technologie and from the Association pour la Recherche contre le Cancer (ARC). The authors declare that there is no conflict of interest that would prejudice the impartiality of this scientific work.

\section{References}

Adachi T, Ono Y, Koh KB, Takashima K, Tainaka H, Matsuno Y, Nakagawa S, Todaka E, Sakurai K, Fukata H et al. 2004 Long-term alteration of gene expression without morphological change in testis after neonatal exposure to genistein in mice: toxicogenomic analysis using cDNA microarray. Food and Chemical Toxicology 42 445-452.

Akingbemi BT 2005 Estrogen regulation of testicular function. Reproductive Biology and Endocrinology 351.

Akingbemi BT, Ge R, Rosenfeld CS, Newton LG, Hardy DO, Catterall JF, Lubahn DB, Korach KS \& Hardy MP 2003 Estrogen receptor-alpha gene deficiency enhances androgen biosynthesis in the mouse Leydig cell. Endocrinology 144 84-93.

Akingbemi BT, Sottas CM, Koulova AI, Klinefelter GR \& Hardy MP 2004 Inhibition of testicular steroidogenesis by the xenoestrogen bisphenol A is associated with reduced pituitary luteinizing hormone secretion and decreased steroidogenic enzyme gene expression in rat Leydig cells. Endocrinology 145 592-603.

Anway MD, Cupp AS, Uzumcu M \& Skinner MK 2005 Epigenetic transgenerational actions of endocrine disruptors and male fertility. Science 308 1466-1469.

Anway MD, Memon MA, Uzumcu M \& Skinner MK 2006 Transgenerational effect of the endocrine disruptor vinclozolin on male spermatogenesis. Journal of Andrology 12 [in press].

Aravindakshan J, Paquet V, Gregory M, Dufresne J, Fournier M, Marcogliese DJ \& Cyr DG 2004 Consequences of xenoestrogen exposure on male reproductive function in spottail shiners (Notropis hudsonius). Toxicological Sciences 78 156-165.

Aschim EL, Giwercman A, Stahl O, Eberhard J, Cwikiel M, Nordenskjold A, Haugen TB, Grotmol T \& Giwercman YL 2005 The Rsal polymorphism in the estrogen receptor-beta gene is associated with male infertility. Journal of Clinical Endocrinology and Metabolism 90 5343-5348.

Atanassova N, McKinnell C, Walker M, Turner KJ, Fisher JS, Morley M, Millar MR, Groome NP \& Sharpe RM 1999 Permanent effects of neonatal estrogen exposure in rats on reproductive hormone levels, Sertoli cell number, and the efficiency of spermatogenesis in adulthood. Endocrinology 140 5364-5373.

Atanassova N, McKinnell C, Turner K, Walker M, Fisher J, Morley M, Millar M, Groome N \& Sharpe R 2000 Comparative effects of neonatal exposure of male rats to potent and weak (environmental) estrogens on spermatogenesis at puberty and the relationship to adult testis size and fertility: evidence for stimulatory effects of low estrogen levels. Endocrinology 141 3898-3908.

Auger J, Kunstmann JM, Czyglik F \& Jouannet P 1995 Decline in semen quality among fertile men in Paris during the past 20 years. New England Journal of Medicine 332 281-285.

Barkley MS, Geschwind II \& Bradford GE 1979 The gestational pattern of estradiol, testosterone and progesterone secretion in selected strains of mice. Biology of Reproduction 20 733-738.

Barnhoorn IE, Bornman MS, Pieterse GM \& van Vuren JH 2004 Histological evidence of intersex in feral sharptooth catfish (Clarias gariepinus) from an estrogen-polluted water source in Gauteng, South Africa. Environmental Toxicology 19 603-608.

Bellido C, Pinilla L, Aguilar R, Gaytan F \& Aguilar E 1990 Possible role of changes in post-natal gonadotrophin concentrations on permanent impairment of the reproductive system in neonatally oestrogenized male rats. Journal of Reproduction and Fertility 90 369-374.

Carani C, Qin K, Simoni M, Faustini-Fustini M, Serpente S, Boyd J, Korach KS \& Simpson ER 1997 Effect of testosterone and estradiol in a man with aromatase deficiency. New England Journal of Medicine 337 91-95.

Carreau S, Lambard S, Delalande C, Denis-Galeraud I, Bilinska B \& Bourguiba S 2003 Aromatase expression and role of estrogens in male gonad: a review. Reproductive Biology and Endocrinology 1 35-41.

Chu S \& Fuller PJ 1997 Identification of a splice variant of the rat estrogen receptor beta gene. Molecular and Cellular Endocrinology 132 195-199.

Cooke PS \& Eroschenko VP 1990 Inhibitory effects of technical grade methoxychlor on development of neonatal male mouse reproductive organs. Biology of Reproduction 42 585-596.

Cupp A \& Skinner M 2001 Actions of the endocrine disruptor methoxychlor and its estrogenic metabolite on in vitro enbryonic rat seminiferous cord formation and perinatal testis growth. Reproductive Toxicology 15 317-326.

Davenport M 1997 Risk of testicular cancer in boys with cryptorchidism. Study was based on small number of cancers. BMJ 315 1462-1463.

De Guise S, Lagace A \& Beland P 1994 True hermaphroditism in a St Lawrence beluga whale (Delphinapterus leucas). Journal of Wildlife Diseases 30 287-290.

De Solla SR, Bishop CA, Van der Kraak G \& Brooks RJ 1998 Impact of organochlorine contamination on levels of sex hormones and external morphology of common snapping turtles (Chelydra serpentina serpentina) in Ontario, Canada. Environmental Health Perspectives 106 253-260.

Deladoey J, Fluck C, Bex M, Yoshimura N, Harada N \& Mullis PE 1999 Aromatase deficiency caused by a novel P450arom gene mutation: impact of absent estrogen production on serum gonadotropin concentration in a boy. Journal of Clinical Endocrinology and Metabolism 84 4050-4054.

Delbes G, Levacher C, Pairault C, Racine C, Duquenne C, Krust A \& Habert R 2004 Estrogen receptor \{beta\}-mediated inhibition of male germ cell line development in mice by endogenous estrogens during perinatal life. Endocrinology 145 3395-3403.

Delbes G, Levacher C, Duquenne C, Racine C, Pakarinen P \& Habert $R$ 2005 Endogenous estrogens inhibit mouse fetal Leydig cell development via estrogen receptor alpha. Endocrinology $\mathbf{1 4 6}$ 2454-2461.

Edwards TM, Moore BC \& Guillette LJ Jr 2006 Reproductive dysgenesis in wildlife: a comparative view. International Journal of Andrology 29 109-121. 
Facemire CF, Gross TS \& Guillette LJ Jr 1995 Reproductive impairment in the Florida panther: nature or nurture? Environmental Health Perspectives 103 79-86.

Fielden MR, Halgren RG, Tashiro CH, Yeo BR, Chittim B, Chou K \& Zacharewski TR 2001 Effects of gestational and lactational exposure to Aroclor 1242 on sperm quality and in vitro fertility in early adult and middle-aged mice. Reproductive Toxicology 15 281-292.

Fielden MR, Halgren RG, Fong CJ, Staub C, Johnson L, Chou K \& Zacharewski TR 2002 Gestational and lactational exposure of male mice to diethylstilbestrol causes long-term effects on the testis, sperm fertilizing ability in vitro, and testicular gene expression. Endocrinology 143 3044-3059.

Fielden MR, Samy SM, Chou KC \& Zacharewski TR 2003 Effect of human dietary exposure levels of genistein during gestation and lactation on long-term reproductive development and sperm quality in mice. Food and Chemical Toxicology 41 447-454.

Fry DM 1995 Reproductive effects in birds exposed to pesticides and industrial chemicals. Environmental Health Perspectives 103 165-171.

Fry DM \& Toone CK 1981 DDT-feminization of gull embryos. Science 213 922-924.

Glaze GM 1984 Diethylstilbestrol exposure in utero: review of literature. Journal of the American Osteopathic Association 83 435-438.

Goyal HO, Robateau A, Braden TD, Williams CS, Srivastava KK \& Ali K 2003 Neonatal estrogen exposure of male rats alters reproductive functions at adulthood. Biology of Reproduction 68 2081-2091.

Greco TL \& Payne AH 1994 Ontogeny of expression of the genes for steroidogenic enzymes P450 side-chain cleavage, 3 beta-hydroxysteroid dehydrogenase, P450 17 alpha-hydroxylase/C17-20 lyase, and P450 aromatase in fetal mouse gonads. Endocrinology 135 262-268.

Greco TL, Furlow JD, Duello TM \& Gorski J 1992 Immunodetection of estrogen receptors in fetal and neonatal male mouse reproductive tracts. Endocrinology 130 421-429.

Green S, Walter P, Kumar V, Krust A, Bornert JM, Argos P \& Chambon P 1986 Human oestrogen receptor cDNA: sequence, expression and homology to v-erb-A. Nature 320 134-139.

Guillette LJ Jr \& Guillette EA 1996 Environmental contaminants and reproductive abnormalities in wildlife: implications for public health? Toxicology and Industrial Health 12 537-550.

Guillette LJ Jr, Gross TS, Masson GR, Matter JM, Percival HF \& Woodward AR 1994 Developmental abnormalities of the gonad and abnormal sex hormone concentrations in juvenile alligators from contaminated and control lakes in Florida. Environmental Health Perspectives 102 680-688.

Haavisto TE, Adamsson NA, Myllymaki SA, Toppari J \& Paranko J 2003 Effects of 4-tert-octylphenol, 4-tert-butylphenol, and diethylstilbestrol on prenatal testosterone surge in the rat. Reproductive Toxicology 17 593-605.

Habert R \& Picon R 1984 Testosterone, dihydrotestosterone and estradiol-17 beta levels in maternal and fetal plasma and in fetal testes in the rat. Journal of Steroid Biochemistry 21 193-198.

Habert R, Lejeune H \& Saez JM 2001 Origin, differentiation and regulation of fetal and adult Leydig cells. Molecular and Cellular Endocrinology 179 47-74.

Haqq CM, King CY, Donahoe PK \& Weiss MA 1993 SRY recognizes conserved DNA sites in sex-specific promoters. PNAS $\mathbf{9 0}$ 1097-1101.

Hayes T, Haston K, Tsui M, Hoang A, Haeffele C \& Vonk A 2003 Atrazine-induced hermaphroditism at $0.1 \mathrm{ppb}$ in American leopard frogs (Rana pipiens): laboratory and field evidence. Environmental Health Perspectives 111 568-575.

Herrmann BL, Saller B, Janssen OE, Gocke P, Bockisch A, Sperling H, Mann K \& Broecker M 2002 Impact of estrogen replacement therapy in a male with congenital aromatase deficiency caused by a novel mutation in the CYP19 gene. Journal of Clinical Endocrinology and Metabolism 87 5476-5484.
Hirata S, Shoda T, Kato J \& Hoshi K 2003 Isoform/variant mRNAs for sex steroid hormone receptors in humans. Trends in Endocrinology and Metabolism 14 124-129.

Jefferson W, Couse J, Banks E, Korach K \& Newbold R 2000 Expression of estrogen receptor $\mathrm{b}$ is developmentally regulated in reproductive tissues of male and female mice. Biology of Reproduction 62 310-317.

Jobling S, Coey S, Whitmore JG, Kime DE, Van Look KJ, McAllister BG, Beresford N, Henshaw AC, Brighty G, Tyler CR \& Sumpter JP 2002 Wild intersex roach (Rutilus rutilus) have reduced fertility. Biology of Reproduction 67 515-524.

Kaleva M, Virtanen HE, Haavisto AM, Main KM, Reunanen M, Skakkebaek NE \& Toppari J 2005 Circannual rhythm in the incidence of cryptorchidism in Finland. International Journal of Andrology 28 53-57.

Kubota Y, Temelcos C, Bathgate RA, Smith KJ, Scott D, Zhao C \& Hutson JM 2002 The role of insulin 3, testosterone, Mullerian inhibiting substance and relaxin in rat gubernacular growth. Molecular Human Reproduction 8 900-905.

Kuiper GG, Enmark E, Pelto-Huikko M, Nilsson S \& Gustafsson JA 1996 Cloning of a novel receptor expressed in rat prostate and ovary. PNAS 93 5925-5930.

Kuiper GG, Carlsson B, Grandien K, Enmark E, Haggblad J, Nilsson S \& Gustafsson JA 1997 Comparison of the ligand binding specificity and transcript tissue distribution of estrogen receptors alpha and beta. Endocrinology 138 863-870.

Lambard S, Silandre D, Delalande C, Denis-Galeraud I, Bourguiba S \& Carreau S 2005 Aromatase in testis: expression and role in male reproduction. Journal of Steroid Biochemistry and Molecular Biology 95 63-69.

Lassurguere J, Livera G, Habert R \& Jegou B 2003 Time- and doserelated effects of estradiol and diethylstilbestrol on the morphology and function of the fetal rat testis in culture. Toxicological Sciences 73 160-169.

Li H, Papadapoulos V, Vidic B, Dym M \& Culty M 1997 Regulation of rat testis gonocyte proliferation by platelet-derived growth factor and estradiol: identification of signaling mechanisms involved. Endocrinology 138 1289-1298.

Lu B, Leygue E, Dotzlaw H, Murphy LJ, Murphy LC \& Watson PH 1998 Estrogen receptor-beta mRNA variants in human and murine tissues. Molecular and Cellular Endocrinology 138 199-203.

Luconi M, Forti G \& Baldi E 2002 Genomic and nongenomic effects of estrogens: molecular mechanisms of action and clinical implications for male reproduction. Journal of Steroid Biochemistry and Molecular Biology 80 369-381.

Mackenzie CA, Lockridge A \& Keith M 2005 Declining sex ratio in a first nation community. Environmental Health Perspectives 113 1295-1298.

Maffei L, Murata Y, Rochira V, Tubert G, Aranda C, Vazquez M, Clyne CD, Davis S, Simpson ER \& Carani C 2004 Dysmetabolic syndrome in a man with a novel mutation of the aromatase gene: effects of testosterone, alendronate, and estradiol treatment. Journal of Clinical Endocrinology and Metabolism 89 61-70.

Mahendroo MS, Cala KM, Landrum DP \& Russell DW 1997 Fetal death in mice lacking 5 alpha-reductase type 1 caused by estrogen excess. Molecular Endocrinology 11 917-927.

Majdic G, McNeilly A, Sharpe R, Evans L, Groome N \& Saunders P 1997 Testicular expression of inhibin and activin subunits in the rat and human fetus and neonate and during postnatal development in the rat. Endocrinology 138 2136-2147.

Mansfield KG \& Land ED 2002 Cryptorchidism in Florida panthers: prevalence, features, and influence of genetic restoration. Journal of Wildlife Diseases 38 693-698.

Mittre Herve MH, Kottler ML \& Pura M 2004 Human gene mutations. Gene symbol: CYP19. Disease: aromatase deficiency. Human Genetics 114224.

Moller H \& Skakkebaek NE 1999 Risk of testicular cancer in subfertile men: case-control study. BMJ 318 559-562. 
Moore JT, McKee DD, Slentz-Kesler K, Moore LB, Jones SA, Horne EL, Su JL, Kliewer SA, Lehmann JM \& Willson TM 1998 Cloning and characterization of human estrogen receptor beta isoforms. Biochemical and Biophysical Research Communications 247 75-78.

Moreno SG, Dutrillaux B \& Coffigny H 2001 Status of p53, p21, mdm2, $\mathrm{pRb}$ proteins, and DNA methylation in gonocytes of control and gamma-irradiated rats during testicular development. Biology of Reproduction 64 1422-1431.

Morishima A, Grumbach MM, Simpson ER, Fisher C \& Qin K 1995 Aromatase deficiency in male and female siblings caused by a novel mutation and the physiological role of estrogens. Journal of Clinical Endocrinology and Metabolism 80 3689-3698.

Murono EP, Derk RC \& de Leon JH 1999 Biphasic effects of octylphenol on testosterone biosynthesis by cultured Leydig cells from neonatal rats. Reproductive Toxicology 13 451-462.

O'Donnell L, Robertson KM, Jones ME \& Simpson ER 2001 Estrogen and spermatogenesis. Endocrine Reviews 22 289-318.

Olaso R \& Habert R 2000 Genetic and cellular analysis of male germ cell development. Journal of Andrology 21 497-511.

Orth JM, Gunsalus GL \& Lamperti AA 1988 Evidence from sertoli celldepleted rats indicates that spermatid number in adults depends on numbers of sertoli cells produced during perinatal development. Endocrinology 122 787-794.

Oskam IC, Ropstad E, Dahl E, Lie E, Derocher AE, Wiig O, Larsen S, Wiger R \& Skaare JU 2003 Organochlorines affect the major androgenic hormone, testosterone, in male polar bears (Ursus maritimus) at Svalbard. Journal of Toxicology and Environmental Health. Part A 66 2119-2139.

Perez-Martinez C, Garcia-Iglesias M, Ferreras-Estrada M, BravoMoral A, Espinosa-Alvarez J \& escudero-Diez A 1996 Effects of in utero exposure to zeranol or diethylstilbestrol on morphological development of the fetal testis in mice. Journal of Comparative Pathology 114 407-418.

Rajpert-De Meyts E, Jorgensen N, Brondum-Nielsen K, Muller J \& Skakkebaek NE 1998 Developmental arrest of germ cells in the pathogenesis of germ cell neoplasia. APMIS 106 198-204 (Discussion 204-196).

Rouiller-Fabre L, Carmona S, Abou-Merhi R, Cate R, Habert R \& Vigier B 1998 Effect of anti-Müllerian hormone (AMH) on Sertoli and Leydig cell functions in fetal and immature rats. Endocrinology 139 1213-1220.

Saez JM 1994 Leydig cells: endocrine, paracrine and autocrine regulation. Endocrine Reviews 15 574-626.

Safe S 2005 Clinical correlates of environmental endocrine disruptors. Trends in Endocrinology and Metabolism 16 139-144.

Saunders PT 2005 Does estrogen receptor beta play a significant role in human reproduction? Trends in Endocrinology and Metabolism 16 222-227.

Saunders P, Majdic G, Parte P, Millar M, Fisher J, Turner K \& Sharpe R 1997 Fetal and perinatal influence of xenoestrogens on testis gene expression. In The Fate of the Male Germ Cells, pp 99-110. Ed. IA Holstein. New York: Plenum Press.

Saunders P, Fisher J, Sharpe R \& Millar M 1998 Expression of oestrogen receptor beta (ER beta) occurs in multiple cell types, including some germ cells, in the rat testis. Journal of Endocrinology 156 R13-R17.

Saunders PT, Sharpe RM, Williams K, Macpherson S, Urquart H, Irvine DS \& Millar MR 2001 Differential expression of oestrogen receptor alpha and beta proteins in the testes and male reproductive system of human and non-human primates. Molecular Human Reproduction 7 227-236.

Sharpe RM \& Irvine DS 2004 How strong is the evidence of a link between environmental chemicals and adverse effects on human reproductive health? BMJ 328 447-451.

Sharpe RM \& Skakkebaek NE 1993 Are oestrogens involved in falling sperm counts and disorders of the male reproductive tract? Lancet 341 1392-1395.

Sharpe R, Atanassova N, McKinnell C, Parte P, Turner K, Fisher J, Kerr J, Groome N, Macpherson S, Millar M et al. 1998
Abnormalities in functional development of the sertoli cells in rats treated neonatally with diethylstibestrol: a possible role for estrogens in sertoli cell development. Biology of Reproduction 591084.

Sharpe RM, Rivas A, Walker M, McKinnell C \& Fisher JS 2003 Effect of neonatal treatment of rats with potent or weak (environmental) oestrogens, or with a GnRH antagonist, on Leydig cell development and function through puberty into adulthood. International Journal of Andrology 26 26-36.

Skakkebaek NE \& Jorgensen N 2005 Testicular dysgenesis and fertility. Andrologia 37 217-218.

Skakkebaek NE, Bancroft J, Davidson DW \& Warner P 1981 Androgen replacement with oral testosterone undecanoate in hypogonadal men: a double blind controlled study. Clinical Endocrinology $\mathbf{1 4}$ 49-61.

Skakkebaek NE, Rajpert-De Meyts E \& Main KM 2001 Testicular dysgenesis syndrome: an increasingly common developmental disorder with environmental aspects. Human Reproduction 16 972-978.

Smith EP, Boyd J, Frank GR, Takahashi H, Cohen RM, Specker B, Williams TC, Lubahn DB \& Korach KS 1994 Estrogen resistance caused by a mutation in the estrogen-receptor gene in a man. New England Journal of Medicine 331 1056-1061.

Spearow JL \& Barkley M 2001 Reassessment of models used to test xenobiotics for oestrogenic potency is overdue. Human Reproduction 16 1027-1029.

Storgaard L, Bonde JP \& Olsen J 2006 Male reproductive disorders in humans and prenatal indicators of estrogen exposure. A review of published epidemiological studies. Reproductive Toxicology 21 4-15.

Strohsnitter WC, Noller KL, Hoover RN, Robboy SJ, Palmer JR, Titus-Ernstoff L, Kaufman RH, Adam E, Herbst AL \& Hatch EE 2001 Cancer risk in men exposed in utero to diethylstilbestrol. Journal of the National Cancer Institute 93 545-551.

Swan SH, Main KM, Liu F, Stewart SL, Kruse RL, Calafat AM, Mao CS, Redmon JB, Ternand CL, Sullivan S et al. 2005 Decrease in anogenital distance among male infants with prenatal phthalate exposure. Environmental Health Perspectives 113 1056-1061.

Tena-Sempere M, Navarro J, Pinilla L, Gonzalez LC, Huhtaniemi I \& Aguilar E 2000 Neonatal exposure to estrogen differentially alters estrogen receptor alpha and beta mRNA expression in rat testis during postnatal development. Journal of Endocrinology 165 345-357.

Thomas P, Pang Y, Filardo EJ \& Dong J 2005 Identity of an estrogen membrane receptor coupled to a $\mathrm{G}$ protein in human breast cancer cells. Endocrinology 146 624-632.

Thuillier R, Wang Y \& Culty M 2003 Prenatal exposure to estrogenic compounds alters the expression pattern of platelet-derived growth factor receptors alpha and beta in neonatal rat testis: identification of gonocytes as targets of estrogen exposure. Biology of Reproduction 68 867-880.

Toppari J 2002 Environmental endocrine disrupters and disorders of sexual differentiation. Seminars in Reproductive Medicine 20 305-312.

Tsai-Morris CH, Knox G, Luna S \& Dufau ML 1986 Acquisition of estradiol-mediated regulatory mechanism of steroidogenesis in cultured fetal rat Leydig cells. Journal of Biological Chemistry $26 \mathbf{1}$ 3471-3474.

Van Pelt A, De Rooij D, Van der Burg B, Van der Saag P, Gustafsson J \& Kuiper G 1999 Ontogeny of estrogen receptor-beta expression in rat testis. Endocrinology 140 478-483.

Virtanen HE, Rajpert-De Meyts E, Main KM, Skakkebaek NE \& Toppari J 2005 Testicular dysgenesis syndrome and the development and occurrence of male reproductive disorders. Toxicology and Applied Pharmacology 207 501-505.

Vom Saal FS, Cooke PS, Buchanan DL, Palanza P, Thayer KA, Nagel SC, Parmigiani S \& Welshons WV 1998 A physiologically based approach to the study of bisphenol $\mathrm{A}$ and other estrogenic 
chemicals on the size of reproductive organs, daily sperm production, and behavior. Toxicology and Industrial Health $\mathbf{1 4}$ 239-260.

Vos JG, Dybing E, Greim HA, Ladefoged O, Lambre C, Tarazona JV, Brandt I \& Vethaak AD 2000 Health effects of endocrine-disrupting chemicals on wildlife, with special reference to the European situation. Critical Reviews in Toxicology 30 71-133.

Wang Y, Thuillier R \& Culty M 2004 Prenatal estrogen exposure differentially affects estrogen receptor-associated proteins in rat testis gonocytes. Biology of Reproduction 71 1652-1664.

Weniger JP \& Zeis A 1988 Stimulation of aromatase activity in the fetal rat testis by cyclic AMP and FSH. Journal of Endocrinology 118 485-489.
Wilcox AJ, Baird DD, Weinberg CR, Hornsby PP \& Herbst AL 1995 Fertility in men exposed prenatally to diethylstilbestrol. New England Journal of Medicine 332 1411-1416.

Yasuda Y, Kihara T \& Tanimura T 1985a Effect of ethinyl estradiol on the differentiation of mouse fetal testis. Teratology 32 113-118.

Yasuda Y, Kihara T, Tanimura T \& Nishimura H 1985b Gonadal dysgenesis induced by prenatal exposure to ethinyl estradiol in mice. Teratology 32 219-227.

Received 23 March 2006

First decision 14 July 2006

Accepted 14 August 2006 